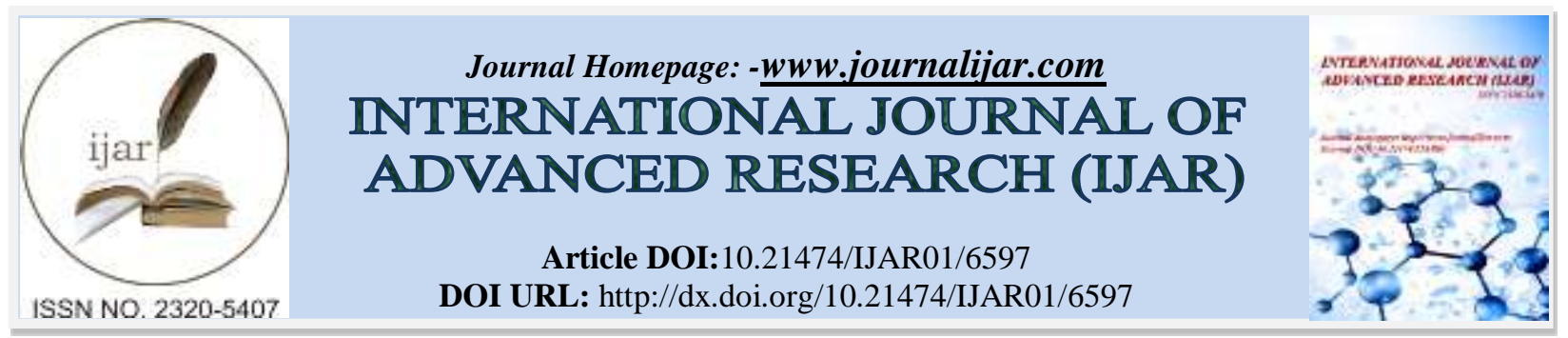

RESEARCH ARTICLE

\title{
AUTOLOGOUS SERUM INJECTION IN CHRONIC URTICARIAL.
}

Dhari Kettan Aouda Aladwan and Saja Mohammed Abbas.

1. MBChB, DVD (dermatology)Head of department of dermatology, Al-Yarmouk Teaching Hospital

2. MBChB, DVD (dermatology), Dermatologist, Al-Yarmouk Teaching Hospital.

\section{Manuscript Info}

Manuscript History

Received: 20 December 2017

Final Accepted: 22 January 2018

Published: February 2018

Keywords:-

Chronic urticaria. Autologous serum skin test. Autoimmune urticaria.

\section{Abstract}

Background: Chronic urticaria is usually diagnosed when wheals occur daily or almost daily associated with redness and itching for more than 42 days due to leak of fluid from blood vessels in the dermis, however, these symptoms often on and off. It is one of the demanding and bothersome therapeutic problems seen by dermatologist and it is classified according to the aggravating factors, among the aggravation factors are the autoantibody.

The aim: To assess the effectiveness of autologous serum therapy in treatment of chronic urticaria

Patients and method: Five $\mathrm{ml}$ venous blood was withdrawn from the patient arm, centrifuged in sterile tube (4000 RPM) for 10 minutes, 2 $3 \mathrm{cc}$ of the patient serum was injected intramuscularly, the process was repeated weekly for 9 weeks and the patients were followed up to 21 weeks. Disease assessment was done clinically, the need for antihistamines and the effect of the disease on quality of life of the patient and observation of any complications.

Results: Thirty patients were included in the current study. Their age ranged from $16-58$ years, the commonest age group affected was $21-$ 30 years, there were 19 females $(63.33 \%)$ and 11 males $(36.66 \%)$, female to male ratio was 1.7:1. Duration of symptoms varies from less than one year to more than 10 years. Fifty percent of the involved patients completely responded to this form of treatment and $40 \%$ had partial improvement. Response to treatment is related to the duration of symptoms, age and gender of the affected patients.

Conclusions: There is promising response of this type of treatment. Better response are reported in females, age between 30 and 50 years and with shorter duration of symptoms.

Copy Right, IJAR, 2018,. All rights reserved.

\section{Introduction:-}

Chronic urticaria is usually diagnosed when wheals occur daily or almost daily associated with redness and itching for more than 42 days ${ }^{(11)}$ due to leak of fluid from blood vessels in the dermis, however, these symptoms often on and off. The main features are itching and appearance of wheals as a raised red or white skin lesion. How frequent $\mathrm{CU}$ is prevalent is not known, however, Greaves ${ }^{(5)}$ stated that it occurs in $0.1-3 \%$ of the population. 
It is one of the demanding and bothersome therapeutic problems seen by dermatologist ${ }^{(1)}$ and it is classified according to the aggravating factors, among the aggravation factors are the autoantibody.

Since 1993, Hide et al ${ }^{(6)}$ partially resolved the autoimmune issue of the problem, these autoantibodies are reported in $27-61 \%$ of patients with chronic urticaria ${ }^{(3),(9)}$. This is why some patients respond well to steroid therapy. Staubach et al in 2006 defined the benefit from the serial intramuscular injections of autologous whole blood therapy in the treatment of this type of urticaria and other problems like atopic dermatitis. ${ }^{(10)}$

\section{The aim:-}

To assess the effectiveness of autologous serum therapy in treatment of chronic urticaria in relation to the age, gender and duration of disease.

\section{Patients and method:-}

The current study was conducted at dermatology consultation unit in Al-Yarmouk Teaching Hospital during the period from August 2016 to September 2017. It included 30 patients. All patients presented with chronic urticaria which failed to responsed to other forms of treatment.

\section{Inclusion criteria:-}

1. Age: all ages

2. Gender: both

3. Duration of symptoms: any duration more than 6 weeks

\section{Exclusion criteria:-}

1. Patients on other form of treatment

2. Patient with risk of upper airway obstruction

3. Patients who failed to attend the follow up

4. Patients who have chronic systemic diseases

Full history was taken and thorough physical examination was conducted to all patients. Ethically the procedure was explained to all and written consent was taken from every patient.

Five cc venous blood was withdrawn from the patient arm, centrifuged in sterile tube (4000 RPM) for 10 minutes, 2 $3 \mathrm{ml}$ of the patient serum was injected intramuscularly, the process was repeated weekly for 9 weeks and the patients were followed up to 24 weeks. Disease assessment was done clinically, the need for antihistamines and the effect of the disease on quality of life of the patient and observation of any complications.

\section{Results:-}

Thirty patients included in the current study. Their age ranged from $16-58$ years, there were 19 females $(63.33 \%)$ and 11 males $(36.66 \%)$, female to male ratio was 1.7:1.

Table no. 1:- Age distribution among the studied group

\begin{tabular}{|l|l|l|l|l|l|}
\hline Age groups & No. & $\%$ & Age groups & No. & $\%$ \\
\hline $1-10$ & - & - & $31-40$ & 7 & $23.3 \%$ \\
\hline $11-20$ & 3 & $10 \%$ & $41-50$ & 8 & $26.6 \%$ \\
\hline $21-30$ & 11 & $36.3 \%$ & $>51$ & 1 & $3.3 \%$ \\
\hline
\end{tabular}

Table no. 2:- The duration of the patient's symptoms

\begin{tabular}{|c|c|c|}
\hline Duration in years & No. of patients & $\%$ \\
\hline$<1$ & 9 & $30 \%$ \\
\hline 1 & 10 & $33.3 \%$ \\
\hline 2 & 6 & $20 \%$ \\
\hline 3 & 2 & $6.6 \%$ \\
\hline 4 & - & - \\
\hline 5 & 1 & $3.3 \%$ \\
\hline 6 & 1 & $3.3 \%$ \\
\hline 7 & - & - \\
\hline
\end{tabular}




\begin{tabular}{|c|c|c|}
\hline 8 & - & - \\
\hline 9 & - & - \\
\hline 10 & 1 & $3.3 \%$ \\
\hline
\end{tabular}

This table revealed that nearly two thirds of the patients (19 patients, $63.3 \%)$ have the symptoms for one year or less and only $3.3 \%$ of the patients have the symptoms for 10 years.

Table no. 3:- The response to treatment

\begin{tabular}{|c|c|c|c|c|c|c|c|c|}
\hline & \multicolumn{4}{|c|}{$\begin{array}{c}\text { Complete } \\
\text { response } \\
\text { (disappearance of } \\
\text { symptoms) }\end{array}$} & \multicolumn{2}{|c|}{$\begin{array}{l}\text { Partial improvement } \\
\text { (symptoms appears } \\
\text { with certain } \\
\text { aggravating factors } \\
\text { after the } 9^{\text {th }} \text { session) }\end{array}$} & \multicolumn{2}{|c|}{$\begin{array}{c}\text { No response } \\
\text { (no signs of } \\
\text { improvement after } \\
\text { the } 9^{\text {th }} \text { session) }\end{array}$} \\
\hline & \multicolumn{2}{|c|}{ No. } & \multicolumn{2}{|c|}{$\%$} & No. & $\%$ & No. & $\%$ \\
\hline & \multicolumn{2}{|c|}{15} & \multicolumn{2}{|c|}{$50 \%$} & 12 & $40 \%$ & 3 & $10 \%$ \\
\hline Session No. & \multicolumn{2}{|c|}{$\begin{array}{c}\text { Start of } \\
\text { Response }\end{array}$} & \multicolumn{2}{|c|}{ Relief of symptoms } & & & & \\
\hline & No. & $\%$ & No. & $\%$ & & & & \\
\hline 1 & 2 & $6.6 \%$ & - & - & & & & \\
\hline 2 & 6 & $20 \%$ & 1 & $3.3 \%$ & & & & \\
\hline 3 & 1 & $3.3 \%$ & 3 & $10 \%$ & & & & \\
\hline 4 & 5 & $16.6 \%$ & 1 & $3.3 \%$ & & & & \\
\hline 5 & - & - & 2 & $6.6 \%$ & & & & \\
\hline 6 & 1 & $3.3 \%$ & - & - & & & & \\
\hline 7 & - & - & 5 & $16.6 \%$ & & & & \\
\hline 8 & - & - & 2 & $20 \%$ & & & & \\
\hline 9 & - & - & 1 & 3.3 & & & & \\
\hline
\end{tabular}

Table no. 4:- The relation between the response to treatment to the age, gender and duration of symptoms.

\begin{tabular}{|c|c|c|c|c|c|c|c|}
\hline & Age & Gender & $\begin{array}{l}\text { Duration of } \\
\text { symptoms }\end{array}$ & $\begin{array}{l}\text { Complete } \\
\text { response }\end{array}$ & $\begin{array}{l}\text { Partial } \\
\text { response }\end{array}$ & $\begin{array}{l}\text { No } \\
\text { Response }\end{array}$ & Complications \\
\hline 1 & 33 & ? & $6 y$ & - & $X$ & - & - \\
\hline 2 & 45 & q & $2 y$ & $\mathrm{X}$ & - & - & - \\
\hline 3 & 25 & $\hat{0}$ & $1 \mathrm{y}$ & $X$ & - & - & - \\
\hline 4 & 42 & q & $10 \mathrm{y}$ & - & $X$ & - & - \\
\hline 5 & 40 & q & $2 y$ & $X$ & - & - & - \\
\hline 6 & 26 & 우 & $1 \mathrm{y}$ & - & $X$ & - & - \\
\hline 7 & 30 & $\hat{0}$ & $6 \mathrm{~m}$ & $X$ & - & - & - \\
\hline 8 & 50 & $\hat{0}$ & $3 \mathrm{y}$ & - & - & $X$ & - \\
\hline 9 & 27 & $q$ & $1 \mathrm{y}$ & - & $\mathrm{X}$ & - & - \\
\hline 10 & 50 & q & $2 y$ & $X$ & - & - & - \\
\hline 11 & 58 & 웅 & $5 \mathrm{y}$ & - & $\mathrm{X}$ & - & - \\
\hline 12 & 28 & $q$ & $8 \mathrm{~m}$ & - & $\mathrm{X}$ & - & - \\
\hline 13 & 44 & q & $1 \mathrm{y}$ & $\mathrm{X}$ & - & - & - \\
\hline 14 & 24 & q & $1 \mathrm{y}$ & $\mathrm{X}$ & - & - & - \\
\hline 15 & 33 & $\hat{0}$ & $9 \mathrm{~m}$ & $X$ & - & - & - \\
\hline 16 & 22 & q & $9 \mathrm{~m}$ & - & - & $\mathrm{X}$ & - \\
\hline 17 & 36 & $\hat{0}$ & $1 \mathrm{y}$ & $X$ & - & - & - \\
\hline 18 & 16 & $\hat{0}$ & $2 y$ & $X$ & - & - & - \\
\hline 19 & 35 & $\hat{0}$ & $1 \mathrm{y}$ & - & $\mathrm{X}$ & - & - \\
\hline 20 & 18 & 우 & $8 \mathrm{~m}$ & - & - & $X$ & - \\
\hline 21 & 27 & 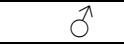 & $2 \mathrm{y}$ & $X$ & - & - & - \\
\hline 22 & 22 & q & $6 \mathrm{~m}$ & $\mathrm{X}$ & - & - & - \\
\hline 23 & 22 & q & $10 \mathrm{~m}$ & - & $\mathrm{X}$ & - & - \\
\hline 24 & 33 & q & $1 \mathrm{y}$ & $X$ & - & - & - \\
\hline
\end{tabular}




\begin{tabular}{|l|l|l|l|l|l|l|l|}
\hline 25 & 45 & 0 & $9 \mathrm{~m}$ & - & $\mathrm{X}$ & - & - \\
\hline 26 & 39 & 0 & $1 \mathrm{y}$ & $\mathrm{X}$ & - & - & - \\
\hline 27 & 17 & 0 & $4 \mathrm{~m}$ & - & $\mathrm{X}$ & - & - \\
\hline 28 & 25 & 0 & $1 \mathrm{y}$ & - & $\mathrm{X}$ & - & - \\
\hline 29 & 50 & 0 & $2 \mathrm{y}$ & - & $\mathrm{X}$ & - & - \\
\hline 30 & 45 & 0 & $3 \mathrm{y}$ & $\mathrm{X}$ & - & - & - \\
\hline $\begin{array}{l}\text { Total } \\
\text { no. }\end{array}$ & & 30 & 15 & 12 & & 3 \\
\hline
\end{tabular}

\section{Discussion:-}

Chronic urticaria is a broad term, it cover both physical, chronic "idiopathic" and urticarial vasculitis. Investigations and treatments are different in physical urticaria were it diverge in important ways from patients with idiopathic chronic urticaria or urticarial vasculitis.

"Chronic "idiopathic" type includes a division with an autoimmune source attributable to circulating autoantibodies against the high affinity IgE receptor (FceR1) and less commonly against IgE". (7) These are better termed as autoimmune urticaria in whom immunosuppressive therapies may be suitable if conventional approaches to management are ineffective. ${ }^{(4)}$

"Although the autologous serum skin test has been proven useful in prompting search for and characterization of circulating wheal-producing factors in chronic urticaria, its specificity as a screening test for presence of functional anti-FceR 1 is low, and confirmation by demonstration of histamine-releasing activity in the patient's serum must be the benchmark test in establishing this diagnosis. Improved screening tests are being sought; for example, ability of the chronic urticaria patient's serum to evoke expression of CD 203c on donor human basophils is showing some promise". ${ }^{(7)}$ These tests form the bases of using autologous serum therapy in CU, however, Bajaj et al concluded that autologous serum skin test reactivity may not consistently reflect the chances of response since many negative patient may also benefited by this form of treatment. ${ }^{(1)}$

Autologous serum is preferred over whole blood in the treatment since the important factors are found in the serum, hence a more comfortable fine needles can be used for injection with no risk of serum clotting. ${ }^{(1)}$

Nearly $15-20 \%$ of population will suffer on one occasion from urticaria during their lifetime and it can affect any person at any age however most frequently after adolescence, young adults being the most common target affected. ${ }^{(5)}$ In the current study, data obtained from table no. 1 revealed that over $80 \%$ of the patients were over the age of 21 years and over one third of them $(36.3 \%)$ were in the $3^{\text {rd }}$ decade of life. These results run parallel to results documented by Deacock who stated that 20 - 40 years period of age was the commonest period for incidence of urticaria. $^{(2)}$

Gender distribution in the current study revealed that females (63.33\%) were more affected than males (36.66\%), female to male ratio was $1.7: 1$. Yadav $\mathrm{S}$ et al in their study stated that CU is twice as common in females as in males ${ }^{(11)}$ and Deacock in his study also revealed that urticaria is more common in females than males. ${ }^{(2)}$

Table no. 2, shows that nearly two thirds of the patients (19 patients, $63.3 \%$ ) have the symptoms for one year and less and only $3.3 \%$ of the patients have the symptoms for 10 years. Bajaj el al in their study revealed that the duration of the disease ranged from 6 months to 32 years if positive autologous serum skin test and reduced to up 10 years in patients with negative skin test. ${ }^{(1)}$

Fifty percent of the involved patients completely responded to this form of treatment as delineated in table no. 3 and $40 \%$ had partial improvement. S.Nageswaramma et al in their studies grouped the patients according to the positivity of autologous serum skin test into 2 groups, they documented that $37.9 \%$ of the +positive test group and $23.8 \%$ of the -negative test group at the end of follow up period showed complete response (collectively $61.7 \%$ ) and mild disease was shown in $27.5 \%$ and $19 \%$ respectively. ${ }^{(8)}$

Table no. 4 reveals the response to treatment in relation to the age, gender and duration of the disease. The complete response group was 15 patients $(50 \%), 7$ were females $(46.6 \%)$ and 8 were males $(53.3 \%)$. The partial response 
group was 12 patients (40\%), females were $10(83.3 \%)$ and males were $2(16.6 \%)$, and the no response group were 3 $(10 \%), 2$ of them were females $(66.6 \%)$. And according to age date better responses were documented when the age of the patients was between 30 and 50 years. Response is expected more when the duration is relatively short as revealed in the same table in the complete response group, 14 (93.3\%) had the symptoms for 2 years and less. Hence, good response is revealed in the studied group, these results run parallel to results documented by Staubach et al. ${ }^{(10)}$ in 2006, they revealed significant reduction in CU activity and decrease in the use of antihistamines by their patients after injection of autologous whole blood.

\section{Conclusions:-}

There is promising response of this type of treatment. Better responses are reported in females, age between 30 and 50 years and with shorter duration of symptoms

\section{References:-}

1. Yadav S, Upadhyay A, Bajaj AK. Chronic urticaria: an overview. Indian J Dermatol 2006; 51:171-7.

2. Greaves MW. Chronic urticaria. N Engl J Med 1995;332:1762-72.

3. Bajaj A K, Saraswat A, Upadhyay A, Damisetty R, Dhar S. Autologous serum therapy in chronic urticaria: Old wine in a new bottle. Indian J Dermatol Venereol Leprol 2008;74:109-13

4. Hide M, Francis DM, Grattan CE, Hakimi J, Kochan JP, Greaves MW. Autoantibodies against the high affinity IgE receptor as a cause of histamine release in chronic urticaria. N Engl J Med 1993;328:1599-604.

5. Godse KV. Autologous serum skin test in chronic idiopathic urticaria. Indian J Dermatol Venereol Leprol 2004;70:283-4.

6. Piconi S, Trabattoni D, Iemoli E, Fusi ML, Villa ML, Milazzo F, et al. Immune profiles of patients with chronic idiopathic urticaria. Int Arch Allergy Immunol 2002;128:59-66.

7. Staubach P, Onnen K, Vonend A, Metz M, Siebenhaar F, Tschentscher I, et al. Autologous whole blood injections to patients with chronic urticaria and a positive autologous serum skin test: A placebo-controlled trial. Dermatology 2006;212:150-9.

8. Macolm W Greaves, Kian Teo Tan. Chronic Urticaria: Recent Advances. Clinical Reviews in Allergy and Immunology. 2007; 33, 1-2, pp $134-43$.

9. Grattan CE, Sabroe RA, Greaves MW. Chronic Urticaria. J Am Acad dermatol. 2002; 46(5): 645-57.

10. Deacock SJ. An approach to the patient with urticaria. Clin Exp Immunol 2008;153:151-61.

11. S.Nageswaramma, V. Lakshmi Sarojini, B.Bhavani Pujitha, G.Sirisha, G.Suma Bindu. Efficacy of Autologous Serum Therapy in Chronic Urticaria. International Journal of Contemporary Medical Research $2017 ; 4$ (1) pp: $110-112$. 